\title{
Why did Czech Banks Switch From Loans in 1995?
}

\author{
Jeffrey H. Nilsen ${ }^{1}$ \\ Studienzentrum Gerzensee and \\ Econ. Dep't, Copenhagen Business School \\ jhn.szgerzensee.ch
}

This Version: 21 April, 1998

First Draft: 8 July, 1997

The Czech banking system is seen by many observers to be the most successful of all former socialist economies'. But have Czech banks successfully provided worthy enterprises with sufficient credit from the funds made available to them? Using data from the Czech National Bank and data on individual Czech banks, I find evidence that in 1995 banks are provided with more deposits, but do not transform them into enterprise loans. I investigate the possible causes of this great portfolio switch and find that the central bank instituted a monetary tightening during a regime of fixed exchange rates and mobile capital. The central bank sterilized the continuing capital inflows. The resulting higher interbank interest rates and competition from foreign funds made the loan interest margin too narrow for Czech banks to profitably lend. The tight money strategy likely contributed to the bank failures in the following year and may have lead to greater concentration in the Czech banking system.

JEL codes: $\quad$ E58, P34

Keywords: $\quad$ Banking, Capital Flows, Capital Mobility, Central Banking, Economy in Transition, Fixed Exchange Rates, Monetary Policy

${ }^{1}$ I have benefitted from discussions with Jan Hanousek, Don Parsons, and especially Niels Blomgren-Hansen and Riccardo Rovelli. I gratefully thank Jan Hanousek, Ceska Narodni Banka and the Bundesbank for data and clarifications. Seminar participants at CEES and the Economics Department at the Copenhagen Business School, and at Humboldt University and CERGE-EI provided very helpful comments. The opinions expressed herein are mine alone, however, and I am responsible for any errors. This research has benefitted from the support of ACE grant P95-2063-R. 


\section{Introduction}

The Czech Republic is at the forefront of central European economies which seek to rebuild institutions that have been based on the planned administration of economic activity. Any economy undergoing such a mammoth transformation is likely to suffer adjustment costs, and the Czech Republic has experienced several years of negative growth while it redesigned its institutions and retrenched for a new environment. In 1994, the Czech economy apparently "turned a corner" and attained positive economic growth for the first time. It has repeated this achievement in each succeeding year. Some authors predict that transition nations may sustain real GDP growth rates two to three times that of European Union nations, but disagreement within the government on how to proceed in the future predicts problems in the Czech case. Annual growth rates of 5\% may thus not persist in the near future.

The banking system in decentralized market economies is important for economic activity, and especially in those nations without well-developed financial markets. In centrally planned economies, banks' sole function was to supply enterprises with funds to fulfill a central production plan. State-owned banks supplied funds to state-owned enterprises simply as a factor of production, without much concern for repayment. In market economies, profit-maximizing behavior by individuals in an environment of uncertainty requires banks to overcome substantial information problems in channeling resources from ultimate savers to ultimate borrowers. And by screening loan applicants and monitoring successful applicants' performance to maximize repayment likelihood, funds will reach those worthy firms requiring loans to finance their investments and working capital.

The Czech banking system is interesting since it has been set up with the help of international organizations, yet is undergoing many changes as it develops. It is widely viewed to be among the best banking system of the former socialist economies. Legislation and regulation has gone to great lengths to provide banks with a clear incentive structure: owner/managers are responsible for profits and losses and may sink or swim. The Czech National Bank, a modern central bank, regulates banks to protect the system while maintaining these incentives. It has allowed some banks to fail while setting up mergers for others. 
This paper focuses on reasons why private banks have not contributed more positively to the Czech transition process. The year 1995 was the second year of positive economic growth in this new market system. Indeed, the Czech Republic attained a strong 4.8\% growth of real GDP. Despite this healthy growth, we observe that Czech banks shifted their portfolios massively from loans to liquid assets. This is puzzling indeed since it is difficult to ignore one's priors that transition nations require a tremendous amount of new investment to modernize the obsolete equipment inherited from the earlier political system. Is it possible that firms have satisfied this pent up demand for loans already in 1995? This shift in portfolio was substantial: it reduced loans on Czech bank balance sheets by around $6 \%$ of their assets, corresponding to nearly $3 \%$ of GDP (CNB). The reasons for the shift gives insight into why banks have not played as prominent a role as expected.

A growing literature seeks to explain the early 1990's U.S. "credit crunch", a particularly severe slow-down in lending, see reviews by Bernanke and Lown (1991) and Sharpe (1995). Despite similarities, e.g. new enforcement of the Basel requirements of capital relative to riskweighted assets, evidence in the Czech case suggests other mechanisms are at work. The Czech Republic at this time enjoyed an improved reputation with foreign investors. Capital in-flows resulted. In a determined effort to achieve an M2 target, the central bank sterilized, i.e. removed much of the effect of these inflows on monetary aggregates. Yet this policy in a fixed exchange rate regime in the absence of capital controls led to higher interest rates, attracting more capital flows and thus requiring yet more sterilization. These policies increased the cost of making loans with domestic deposits and gave an definite advantage to lenders using foreign funds. This advantage was compounded in 1995 when the Czech National Bank imposed a limit on banks' access to shortterm foreign liabilities. Larger Czech and foreign banks were able to circumvent this capital control and thus lend at lower cost for increased profits and market share. Small banks, on the other hand, faced razor thin lending margins, a condition that could help but contribute to the banking problems that surfaced in 1996.

The remainder of this paper is organized as follows. In section II, I briefly review the Czech Republic's recent achievements and sketch in some detail its banking system. In section III, I examine possible "natural" reasons for the Czech bank lending slow-down during the years 1993 
through 1995 using data on a majority of individual Czech banks. In section IV, I turn the focus more fruitfully to monetary policy based explanations. Finally, I conclude in section V with some policy suggestions.

\section{The Czech Republic: Recent Performance}

The Czech Republic has achieved economic progress in 1995 and 1996 that may be favorably compared to developed western economies. It has indeed accomplished many tasks in its goal of becoming an efficient market economy. For example, it has redirected its trade toward the west, reassigned ownership of most of its goods producing firms, reduced substantially the economic activity done under the aegis of the state, maintained low unemployment while reducing inflation, and rapidly built up the foreign exchange reserves needed to maintain its exchange rate target and so withstand volatile capital flows.

At the time of the study, the Czech Republic was at the very turning point, moving from the fourth straight year of negative growth in 1993 to positive and increasingly strong real GDP growth in 1994 (2.8\%) and 1995 (4.8\%). Activity may have been near to capacity: the unemployment rate hovered around 3.5\% each year in the study. This improved performance has been recognized by the cash-rich developed world. Rating agencies such as Moody's have continued to upgrade their estimates of both the country's and the leading banks' repayment likelihoods. As a result, the Czech government and the best banks can now obtain foreign loans at very low premia over the risk-free international lending rate.

One gift inherited from the communists is that the Czech government is not compelled to pay high interest expenses. The very low level of national debt, corresponding to $12 \%$ of GDP in 1995, would easily permit the Czech Republic meet the Maastricht criteria for entry into the European Monetary Union (cf. the 70\% European Union average). The Czech government has not squandered this gift. It has run budget surpluses consistently since 1993 and moreover has not drawn on the credit line made available by the IMF (Camdessus, 1994).

\section{II.A. Development of The Czech Banking System}


Any institution undergoing transformation is likely to reflect traces of its own earlier state. The forerunner of the Czech banking system was a simple instrument of the central planner to channel resources to the state-owned firms in order to fulfill the five-year plan. Remnants of the old system are still visible long after the 1989 velvet revolution, 1991 bank reforms, and January, 1993 bifurcation of Czechoslovakia into the Czech and Slovak Republics. The current banking market is dominated by two banks which comprise about 50\% of total banking system assets (Aspekt database, 1995). The largest bank, Komercni Banka, is a commercial bank and was created in the split-up of the former socialist monobank (the other sibling is the Czech National Bank). The second largest bank, Cesky Sporitelna (representing the remains of the former state savings bank), concentrates on savings and lending to individuals and small firms. The 1991 reforms furthered the banking system 's institutional development towards traditional European banking, which permits universal banking (i.e. banks may make equity investments in firms and engage in investment banking).

The Czech National Bank (CNB hereafter) has been designed to be a modern western central bank. It was created with the help of international organizations such as the International Monetary Fund. It has considerable independence from the government, e.g. CNB governors have 6 year terms. Its primary objective is to defend price stability (and it has achieved surprisingly low inflation rates, e.g. $10 \%$ in 1994 and $9.1 \%$ in 1995). It is also regulates the banking system and in pursuit of this responsibility it is empowered to impose strong sanctions, including to levy fines, take over bank management, and withdraw banking licenses. For greater depositor confidence, it established in 1994 a scheme to insure 80\% of depositors' funds below Czech Koruny (Kc hereafter) 100,000 (approximately 4,000 USD) ${ }^{1}$. Furthermore, it has begun to enforce that each Czech bank attain the same level of capital per risk-weighted assets as EU banks according to the Basel agreement.

In common with many post-socialist states, the Czech banking system has unfortunately inherited a stock of loans made to former state enterprises which have only little likelihood of repayment. The Czech government has dealt with this in a very sensible way. It set up a single

${ }^{1}$ The insurance is funded from bank contributions. Commercial banks must pay $0.5 \%$ of each insured deposit. Savings banks pay only $0.1 \%$. 
consolidation bank, Konsolidacni Banka, as the repository of many questionable loans existing at the time of the changeover. As a result, banks face clear profit incentives: they cannot plausibly point to problems inherited from the socialist system as basis for help from the government or central bank. Moreover, the financial system is less prone to bank failures and their consequences. Since Konsolidacni Banka's performance does not reflect profit-oriented behavior by either its clients or managers (it has a unique license to manage these loans and is not permitted to extend new credits, see Vojtisek, 1993), I drop it from subsequent analysis.

\section{II.B. Current Czech Banking System}

The Czech financial system has not yet developed to incorporate the range of financial instruments found in western Europe. For example, the use of derivatives is limited and mutual funds have not won a large presence. The Prague stock exchange has been criticized by the international business press as prone to manipulation by insiders ${ }^{2}$ and perhaps for this reason has not attracted as much foreign capital as it might otherwise have. As a result, enterprises look mainly to bank loans as an alternative to cheaper internal funds (i.e. retained earnings) for investment.

The current system remains dominated by the two former socialist banks. Not only do they share approximately one-half of total bank system assets in 1995, but thanks in part to their extensive branch networks, they have disproportionate access to nominally cheaper domestic deposit funds (60\% in 1995, Aspekt data). Thanks to the few alternatives to banks as saving instruments and to the state savings subsidy ${ }^{3}$, the average deposit rate hovered within 20 basis points of $7 \%$ during this study, nearly an administered rate. This rate is at least $2 \%$ below the level of inflation, but may yet be less attractive than foreign funds, as I argue in part IV, below.

In addition to the two dominant banks, the system in 1995 consisted of 53 mostly smaller and new banks ${ }^{4}$. Among these are 10 foreign "branches" which include the German giants Commerzbank

${ }^{2}$ The Czech government has been under increasing pressure due to its hand's off attitude with respect to these conditions.

${ }^{3}$ Those Czechs saving for construction projects at licensed savings banks are given a state subsidy of $25 \%$ of their savings (up to Kc 18,000 maximum per annum), see CNB Banking Supervision publication.

${ }^{4}$ The CNB, in agreement with the Czech Finance Ministry, has not licensed any new banks since 1994 in a drive to consolidate the banking system. 
and Deutschebank. They operate exactly like Czech banks with the exception that their parents are responsible for all their commitments (CNB). The CNB states that it treats foreign-owned Czech banks exactly as domestically-owned banks.

One "problem" the Czech National Bank faces is that the stock of national debt does not permit sufficiently thick markets in government debt. The CNB therefore lacks sufficient government paper to drain liquidity from the banking system and carry out its monetary policy intentions. It has thus issued its own debt to carry out monetary policy actions. Due to the low quantity of discount loans requested by private banks, the CNB has often manipulated minimum reserve requirements to absorb liquidity, an instrument often shunned by central banks as being too blunt.

\section{II.C. 1995: Czech Banks' Thirst for Liquidity?}

Many theories predict that bank loans are positively correlated with economic activity. This includes especially those by credit channel theorists, some of whom assign a causal role for bank loans in economic activity (see e.g. Bernanke and Blinder, 1988, Calvo and Coricelli, 1993 and Kashyap and Stein, 1997). Banks earn their highest return from loans as compensation for the chance of loss in making an accurate evaluation of loan applicants' ability and willingness to repay their debts ${ }^{5}$. It is then surprising that in 1995, a year of highly positive real growth, banks switched away from loans by more than $3 \%$ of $\mathrm{GDP}^{6}$ into liquid assets such as cash and short-term bills, instruments which yield lower returns than loans. In their portfolios, the Czech banks' share of loans dropped from $53.2 \%$ of assets to 46.4\% (where it remained in 1996), while securities rose from $12.3 \%$ to $17.4 \%$ in 1995 (CNB). Figure 1 shows that total loans including those denominated in foreign exchange increased slightly in real terms in $1995^{7}$. The right graph shows though, the steep change in the banks' portfolios away from lending.

Despite common features to the 1990's U.S. lending slowdown, e.g. the banks' shift from

${ }^{5}$ The compensation for interest rate risk, possible lost profits due to fluctuating interest rates by paying on liquid liabilities while earning on illiquid assets, is likely less important in the Czech case since $74 \%$ of new credits granted in 1995 were of short-term maturity. (CNB)

${ }^{6}$ The lending reduction does not imply that banks are less important in the Czech financial system since both deposits and total assets increased in real terms (see Boyd and Gertler, 1993).

${ }^{7}$ The figure 1 line with circular symbols is aggregated from Aspekt data, which excludes foreign bank branches. The line with triangular symbols adds the foreign exchange loans from CNB to the aggregate from Aspekt, thus making the conservative assumption that Czech banks made no foreign exchange loans. 
loans was almost fully reflected by a rise in liquid assets at the same time that the central bank began to enforce the Basle capital requirements, this 1995 Czech episode does not seem to be a credit crunch. According to Bernanke and Lown (1991), a credit crunch is “... a significant leftward shift in the supply curve for bank loans, holding constant both the safe real interest rate and the quality of potential borrowers". Neither of these two conditions held. Interbank interest rates, representing Czech banks' lowest source cost of funds, rose in the latter half of 1994, and importantly relative to foreign interest rates. Further, foreign investors' perception of the Czech borrower improved as indicated by repeated ratings upgrades by e.g. Moody's. These points will be developed further in section IV. below.

\section{Are Loan Supply or Demand Factors to Blame?}

In this section, I focus on arguments for the cause of this puzzling slowdown in lending by Czech banks at a time we might expect lending to increase, given the health of the economy and the need to rebuild the nation's infrastructure. One candidate cause I will consider only briefly is based on changes in the stock of bad loans. These "classified" loans, amounting to $38.6 \%$ of total credits ${ }^{8}$ as of 1994 (CNB), no doubt played a role in banks' problems. But the growth of classified loans declined slightly in 1995 (CNB estimate), so in the absence of other information ${ }^{9}$, I seek other explanations for the lending slowdown.

\section{III.A Demand Factors}

It is useful to split the Aspekt data by bank size to see if some segment of the bank sample was disproportionately involved in this switch from loans to liquid assets. Table 1A shows that small banks, those with assets of less than Kc 100 billion (which includes all but 4 banks), were more severely affected: their drop in loans per total assets were double that of the larger banks'. Indeed, small banks reduced total lending even on a nominal basis. Dividing the bank sample on a foreign-local dimension shows that small banks owned by Czechs were affected disproportionately. As seen in table 1C, foreign banks (and these are purely small banks) increased their lending slightly, although their loans to total

\footnotetext{
${ }^{8}$ Banks hold loss reserves amounting to $45 \%$ of the risk-weighted amount of classified loans on their books, thus cutting the potential loss to the banking system (CNB).

${ }^{9}$ The CNB does not publish per-bank data on classified loans.
} 
assets did decrease substantially.

Why then this decline in lending by small banks? Has there been a reduction in loan requests by small firms, those likely to be the main customers of small banks (assuming that large banks have the resources to lend to both small and large firms)? Or have the best small firms switched their loan requests for some reason to larger Czech banks?

It is beyond the scope of this paper to conclusively reject these hypotheses, but several pieces of evidence point to a limited role for demand side effects in the banking sector turmoil of 1994 and 1995 (and 1996). First, Cesky Sporitelna maintained the same loans to total asset ratio between 1994 and 1995. This bank specializes in loans to individuals and small firms. Further, while aggregate Kc loans increased in nominal terms $6.3 \%$ (to $825.7 \mathrm{Kc} \mathrm{bn}$ ), those denominated in foreign currency increased $128.2 \%$ (to $104.3 \mathrm{Kc}$ bn) (CNB). Unfortunately, many of these loans are made by banks outside the data set, most likely by the foreign bank branches (see Table 2). Further, Anderson and Kegels (1997) using Czech Statistical Office firm-level data show that early privatized and de novo (i.e. relatively small) firms faced severe finance constraints, which "appeared to increase in severity from 1993 to 1994" (they had no data for 1995 at the time of writing). Finally, even if some firms did voluntarily switch to larger banks, it is likely that this occurred as a result of price considerations, i.e. large banks offered the less risky small firms a lower interest rate. I will show in part IV, though, that a cost advantage was the likely basis by which the larger banks were able to make these loans.

\section{III.B. Loan Supply Causes}

Some authors have included among the goals of a transition economy's banking system that of being the instrument used by the government to "harden the budget constraint" (Caprio, 1996). Accordingly, what we are observing is that Czech bank managers have awakened to the real substantial losses in making delinquent loans. Czech banks have thus apparently dedicated themselves to henceforth give loans only to "deserving" firms. The lower loans observed thus represents phantom loans, those granted according to earlier (and easier) Czech lending criteria. However, this logic does not compellingly explain the large decline in loans. First, bad loans did not decrease substantially (CNB) which might be expected if short term loans to bad firms were strongly restricted. Foreignowned banks should have been imposing a hard budget constraint all along. As seen in Table 1C, though, their loans increased slightly over the previous year. And there is nothing to suggest that a 
sudden banking sector "enlightenment" occurred in 1995.

A second, perhaps more plausible bank supply argument is one in which banks switch to cash and short term bonds because they fear a liquidity crisis. Such banking behavior was common and well documented in the Great Depression (Friedman and Schwartz, 1963). While it may be reasonable to ascribe it to a transition economy, little evidence exists to support this claim. For example, although banks strongly increase their liquid assets (Figure 1), it is also true that their deposits increase. The Czech deposit insurance, however, covers individuals' deposits only up to a paltry 100,000 Kc (approximately \$4,000). In a time when financial crisis threatens, individuals would reasonably withdraw deposits, but we observe public's currency to deposit ratio unchanged (see Table 3). Further, the liquid assets of the largest two banks also increased. These banks are "too big to fail" in that a serious problem in either bank would very likely spill over to the other banks and instigate system collapse. The CNB, like most central banks, would seek to contain such a crisis at its roots and therefore support both Komercni and Sporitelna banks prior to the outbreak of widespread problems. There is thus little to support an insurance motive for the build-up in liquid assets.

\section{III.C. Adjustment to Basel Capital Requirements}

The Czech Republic ratified the Europe Agreement on February 1, 1995. The goal was to allow a ten year transition period to adjust the nation's legal, institutional and economic systems to encourage an early entry into the EU (see Anderson and Berglof, 1996). Accordingly, in 1995 the CNB began to monitor the banks' risk-weighted capital to ensure compliance with the Basel rules.

The credit crunch literature has focused on the "capital crunch", that phenomenon that bank inspectors were too severe in implementing the Basel requirements, as culprit of the lending problems in the U.S. (see Sharpe, 1995). Has the Czech central bank's pressure on the banks to increase capital been responsible for the decline in real lending? There is little support in this case. Small banks having a low level of own contributed funds per total assets (below $8.5 \%$ in 1994) actually increased their loan market share (Table 1B). Further, in the aggregate, the level of capital to assets remained approximately the same between 1994 to $1995^{10}$, so any pressure on banks to add to their capital could not have had a substantial influence on the banking system as a whole.

${ }^{10}$ Aspekt data; the CNB also reports that in 1995 bank capital adequacy exceeds by $0.6 \%$ the $8 \%$ required by the Basel Commission. 


\section{A Monetary Policy Explanation}

\section{A. Twin Goals: A Fixed Exchange Rate and an M2 Target}

According to policy statements, the CNB focuses on the real exchange rate (along with the real wage) as a key variable in the economy. To stabilize this rate, the CNB has maintained a nominally fixed exchange rate with the U.S. dollar and deutsche mark throughout the period of this study ${ }^{11}$. Fixing exchange rates to that of a low inflation nation is often believed to help reduce a central bank's discretionary monetary policy power to thus "import" low inflation. The ultimate policy goal is to avoid a real appreciation and thus ensure its firms' competitiveness with the nation's main trading partners. A major disadvantage of fixed exchange rates is that they are subject to speculative attacks which may eradicate the central bank's holdings of foreign exchange reserves.

The simple textbook view of monetary policy ineffectiveness under mobile capital and fixed exchange rates is held by most economists (see for example Krugman and Obstfeld, 1997). Yet the CNB's pronounced policy intention in 1995 was inconsistent with this accepted wisdom. "The target was to maintain an annual inflation rate of between $10 \%$ and $12 \%$. The CNB monetary program was directed at reducing inflation in a period of economic growth." (CNB). What happened was that the CNB interpreted higher than targeted M2 growth in 1994 would bring an excessive rate of inflation. Its subsequent attempt to limit money growth in a fixed exchange rate regime in fact succeeded in restricting M2, but ultimately brought high costs to the banking sector.

A model that allows monetary policy to be effective under fixed exchange rates and mobile capital requires a risk premium that is sensitive to the amount of assets the central bank injects into the economy in place of money ${ }^{12}$ (Lewis, 1995). So in the case of a capital inflow, the central bank will sterilize, i.e. replace foreign assets with its own bonds, thus inducing a larger risk premium. This compensate foreign investors for the higher risk of holding Czech-denominated assets so that they will remain indifferent between the foreign and domestic assets. Yet academic research has not found much, if any, empirical support for the effectiveness of sterilization (see again Lewis, 1995). In the Czech case, the sterilization simply raised the interest rate differential to augment the attractiveness of Czech

${ }^{11}$ The CNB maintains the crown to a currency basket of DM and USD (65\% and 35\% respectively) since 1992, when it switched from a wider-based basket.

${ }^{12}$ This is the "portfolio balance" explanation, see page 1937 (Lewis, 1995) 
denominated assets and maintain a high level of capital inflows.

The CNB implemented its combined fixed exchange rate and M2 target strategy in an international environment of an easier monetary policy in nearby Germany and increasing confidence of international investors in the Czech economy, as indicated by ratings improvements by Moody's, S\&P, etc $^{13}$. The initial impact of these influences was that the Czech Republic became a more attractive investment location. In response to some inflows, the CNB began a series of policy moves intended to slow the growth in M2 and protect its inflation goal. The CNB undertook this tightening in several steps commencing with an increase in minimum reserve requirements in June of $1994^{14}$. The CNB's final 1995 tightening move came in August when it again raised the minimum reserve requirements. Ultimately, the policy resulted in a rise in Czech interbank rates that was greater than the rise in US interest rates.

As might be expected, the policy-induced higher interest rates made the Czech denominated assets more attractive, so the inflows accelerated as reflected in the balance of payments (Table 4). The "other capital" category is especially influenced by monetary policy. It includes both long- and shortterm capital flows that often terminate in Czech banks ${ }^{15}$. As shown in the table, the inflows of $31 \mathrm{bn} \mathrm{Kc}$ in 1993 slowed to only 4.2 bn Kc during the first three quarters of 1994 . Following the monetary policy moves, however, they strengthened substantially in the fourth quarter and cumulated in a net inflow of 23 billion Kc. The inflows accelerated during 1995, finally amounting to 115 billion Kc. This corresponds to over 9\% of that year's GDP! Figure 2 (lower left) shows the excess of the Kc rate over the DM rate and expected depreciation. It is differenced, thus showing the change in the German investor's incentive to invest in Czech deposits. The second line of the figure shows the "other" capital flows into the Czech system.

The CNB then imposed capital controls in August of 1995, aiming to force Czech banks to

${ }^{13}$ The first investment grade rating by the CNB's bonds was attained in 1993. Further upgrades occurred in the second and third quarters of 1994.

${ }^{14}$ The CNB discount rate increases in October, 1994 and June, 1995 probably had a minimal impact on monetary policy since discount loan changes amounted to less than $2 \%$ of the 1995 monetary base change.

${ }^{15}$ Foreign direct investment, representing less-easily reversed funds, are relatively insensitive to interest rate changes. Portfolio flows, e.g. to the Prague Stock Exchange, were slow due to low turnover. 
limit their short-term foreign liability exposure to $130 \%$ of their foreign assets. While this restricted foreigners from depositing demand deposits in small Czech banks, it did little to prevent the best Czech banks from acquiring long-term foreign loans ${ }^{16}$. I discuss the ramification of this move later. The capital flows finally subsided in February, 1996 at about the time the CNB instituted a ten-fold widening of the bands around the central parity (to 7.5\%). This gave the CNB freedom to manipulate monetary policy without committing to enter the foreign exchange market, and thus represented the abandonment of the fixed exchange rate.

\section{B. Defending the Monetary Base: Sterilization}

According to standard descriptions of different definitions of money, a central bank can perfectly control only the monetary base, the currency provided to the economy and those deposits of ready funds it holds for commercial banks. Yet in an open economy context, any foreign inflow converted into domestic currency will increase the monetary base. To regain control of the monetary base, the central bank must sterilize, i.e. reduce its assets or increase its liabilities to offset the higher monetary base (see Mishkin, 1995).

The CNB admits to a significant degree of sterilization; almost Kc 130 billion or nearly $11 \%$ of GDP in 1995. This estimate encompasses many influences, since it sums any reduction of central bank assets or rise in non-monetary liabilities. For conservative calculations based rather on intended sterilization, Table 5 shows the CNB nearly doubled sterilization pressure from $37 \%$ of the inflows in 1994 to $68 \%$ in 1995.

The CNB implemented sterilization mainly by issuing its own securities (the limited amount of Czech government debt prevented the CNB from buying bonds from the public). It also engaged in very extraordinary transfers of deposits from commercial banks to its own liabilities. These transactions amounted to over 42 billion $\mathrm{Kc}$ and involved the foreign exchange arising from the sale of the telecommunications company and deposits of the privatization fund. Finally, the CNB increased reserve requirements which have a compound effect on monetary aggregates. Higher reserve requirements have a direct on sterilization due to the fact that it must trade fewer securities to maintain the same pressure on lending. As a result of a $1 \mathrm{Kc}$ inflow deposit, the CNB need sell $(1-\mathrm{rr})$ securities to banks to hold

${ }^{16}$ In one instance in 1995, Komercni bank led a consortium of Czech banks that were given a 5 year loan at a premium of only 20 basis points over the LIBOR interbank rate. 
constant excess reserves. A rise in reserve requirements, though, also cuts the money multiplier, representing banks' (and the nonbank public's) power to expand the monetary base. Higher reserve requirements reduces the bank system's deposit-creating ability since banks must hold a greater share of funds at the central bank rather than lend them out. Table 3 shows that rising Czech reserve requirements contributed to a substantial reduction in the M2 multiplier.

In the following paragraphs, I specify the public's and commercial banks' influence on the M2 multiplier ${ }^{17}$ in order to clarify the discussion. The public selects a share of their money to be held in either demand deposits or currency, thus determining the currency deposit ratio. The banks select the share of reserves they hold above the amount required by the central bank. This determines the excess reserve ratio. Equation (1) gives the definition of the monetary base: the required reserves (in the case where reserves requirements differ on demand and time deposits) plus excess reserves and currency (see Mishkin, 1995 for the case of a common reserve requirement).

(1) $M B=r_{D D} D+r_{T D} T+E R+C$

Rearranging in a form useful to describe the M2 multiplier:

(2) $M B=[T+D]\left[r_{D D}-\frac{T}{T+D}\left(r_{D D}-r_{T D}\right)+\frac{E R}{T+D}+\frac{C}{T+D}\right]$

M2 consists of currency in circulation and demand deposits (M1) plus time deposits and residents' foreign exchange deposit holdings. This gives the following equation, where $t$ is the ratio of time to time plus demand deposits, $\mathrm{c}$ is the ratio of currency to time and demand deposits. I assume f, the ratio of foreign exchange deposits to time plus demand deposits to be zero in the remainder of this analysis ${ }^{18}$.

(3) $\quad M 2=\frac{1+c+f}{[r D D-t(r D D-r T D)+c+e]} M B$

In the Czech experience of 1993 to 1995, it is instructive to trace the private sector's response to the CNB's policy moves (see Table 3). Commercial banks acted rationally to the original $9 \%$ rise in demand deposit reserve requirements: they induced their depositors to switch to time deposits, as indicated by a ratio of time deposits increasing to $59 \%$ of total, non-foreign exchange deposits by the

${ }^{17}$ I focus on M2 since the CNB is most concerned about that monetary aggregate.

${ }^{18}$ The only significant change to this M2 category was due to the CNB-arranged transfer of the SPT purchase deposit from the commercial banks to the CNB and its subsequent deposit abroad. 
end of 1995. This switch, though, added to the banks' cost of using time deposits when the CNB raised the requirement on time deposits by 5.5\%. Further, the increase in the excess reserves to total deposits ratio observed in $1995^{19}$ is consistent with banks anticipating further rises in reserve requirements (which occurred in August, 1996).

As a result of the combined behavior of the public and commercial banks, the banking system's power to expand any change in the monetary base was reduced by over $25 \%{ }^{20}$ (see Table 3 ). Judging from the tone of the annual reports, the CNB viewed this restriction of banking power in money creation as a large success.

\section{C. The Effect on Banks}

Reading the CNB Annual Reports, one is struck by the prominence that the CNB gives to achieving the M2 target. In 1995, for example, the CNB stated its sterilization operations succeeded to "...offsetting almost the entire issue of liquidity [from the foreign inflows]". Yet there was no concern for possible negative ramifications on the banking sector, though the CNB obviously aimed to slow the growth of bank-created money (recall its 27 billion Kc transfer of telecommunications deposits from the commercial banks). A clear indication of the impact on the banking sector is the extremely thin profit margins on loans using interbank deposits, the least-cost domestic source of funds (see again Table 6 and Figure 2).

Bankers in Prague complain that foreign banks have an unfair cost advantage that allows them to make loans on attractive terms to the best Czech firms. Accordingly, Czech banks are relegated to lending to the remaining, less attractive Czech firms. One should not immediately discount this argument as based on protectionist motives. Czech banks do enjoy a "home-court advantage" in the form of an extended branch network. It gives them a captive deposit base on which they pay a belowinflation deposit rate. To account for the true costs of using these deposits for loans, however, on must include the opportunity cost of the reserve requirements (the CNB does not pay interest on reserves).

${ }^{19}$ The increase in reserves may have been too large for the banks to "digest" (their loans rose gradually through the year, while (sterilized) deposits jumped much higher in the fourth quarter).

${ }^{20}$ I use the 1995 excess reserve ratio of $7 \%$ for conservatism. The build up in excess reserves may be in anticipation of further increases in reserve requirements, but it also may be due to (large) banks exploiting a window of opportunity in obtaining low cost long term foreign deposits. 
As Table 6 shows, the CNB's tightening of reserve requirements effectively rendered unprofitable loans using Czech deposits ${ }^{21}$. Moreover, banks with access to German deposits were given an additional cost advantage since the CNB's higher requirements occurred precisely when the Bundesbank was lowering theirs (Bundesbank, 1995). Most inflows into the Czech Republic in 1995 came from Germany (of the $\$ 3.8$ billion increase in foreign bank claims on Czech banks, $43.4 \%$ came from German banks, while only $12.7 \%$ came from the U.S. and $13.1 \%$ from Austria (BIS)).

The CNB policy's final impact on small Czech banks came in the form of a capital control in August, 1995. All banks were restricted from accepting foreign short-term deposits. But since small banks are less likely to have the size necessary for an international presence, they were unable to overcome information problems to accept longer-term foreign debt. This lack of international access further limited their competitiveness and resulted in an extremely low return on their own capital. Table 7 shows that those Czech banks with access to foreign credit were clearly able to achieve greater returns on their own capital than either foreign-owned banks or (a 100 fold difference to) domestic banks relegated to using Czech deposits for funding. The squeeze on smaller banks further allowed those with access to foreign funds to increase their market share of loans by two percent, from $67 \%$ to $69 \%$. The CNB policy, then, brought further problems to smaller banks and plausibly contributed to a 1996 shake-out in which 8 of these banks failed. Some observers estimate a very high cost of these failures on the Czech economy ${ }^{22}$, with consequences that may be felt beyond the near future.

\section{D. Policy Evaluation}

The Czech economy did very well in 1995, attaining high real growth, low unemployment and relatively low inflation. This is an especially great achievement when it is remembered where this nation was only 6 years earlier. Some of the credit goes to the Czech National Bank for its monetary policies. Real growth, however, slowed somewhat in 1996 and with the eight bank failures in 1996 may indicate that policy makers could learn from the experience of 1995. In this section, I examine the

${ }^{21}$ The relatively low Czech interbank rate is explained by Cesky Sporitelna's role as main supplier of these funds and the savings subsidy scheme cited in footnote 3.

${ }^{22}$ The Economist estimates that between 1991 and 1997 bank crises in the Czech Republic imposed a cost of over $10 \%$ of GDP. 
CNB's performance in achieving its targets.

The CNB's goal was obviously to avoid an appreciation of the real exchange rate in order to maintain the competitiveness of Czech producers and simultaneously to avoid overheating the real sector and thus achieve low inflation. This strategy did not succeed in bringing inflation convergence to either the dollar or DM levels. And so despite the CNB's great efforts, the Kc appreciated substantially in real terms against both currencies.

The CNB held to its M2 target in a very determined way, but in so doing, it raised interest rates above the level consistent with devaluation expectations and the inflation differential, making Czech denominated instruments more attractive for international investors. At the end of 1995, the M2 target was nearly in its acceptable range while the nominal exchange rate was successfully defended. The victory was costly, however: an appreciated real exchange rate and troubles in the banking sector. Policy makers might have expected inflation to be stubborn, so they better would have allowed a less precisely fixed exchange rate policy vs. the U.S. and Germany. After all, inflation differentials lead to nominal depreciations in the long run, according to Mussa's (1979) stylized facts.

Was it an unstated CNB goal to cull out weak Czech banks? After all, the CNB was so concerned about an previous increase in banks that it declined to issue any new banking licenses between 1993 and 1995. If it was a policy, though, other means could have been used that avoided hurting the entire small Czech bank sector. Another question: was it a specific CNB goal to build up foreign exchange reserves? After all, other former socialist economies such as Hungary and Poland built up similar "war chests". Accordingly, the CNB may have sought to reassure foreign investors that the Czech Republic was solvent and an attractive area to invest less easily reversed funds. These questions are left for future research.

\section{Summary and Conclusions}

The Czech Republic, a success among those nations emerging from the planned economic systems of central Europe, has witnessed banks shifting massively away from loans during a time of high economic growth. I find the Czech National Bank's attempt to restrict M2 growth in an environment of fixed exchange rates and free capital movements the proximate cause. This policy brought higher market interest rates that accelerated capital inflows in the third quarter of 1994 . The 
Czech National Bank viewed these inflows as requiring sterilization to drain liquidity from the economy.

Czech banks' build up of short-term paper was one result, and smaller banks' lower competitiveness vs. foreign banks was another.

While the 1994-1995 monetary policy seems to have been misdirected, it is also reasonable to ask whether the Czech Republic could have allowed greater bank lending without facing higher inflation? With $3 \frac{1}{2} \%$ unemployment, well below the natural rate of most economies, the CNB may be congratulated for maintaining to its strong anti-inflation policies. And after all, just six years earlier this nation did not worry about inflation or bank competition. The CNB's strategy kept inflation admirably low and built up foreign exchange reserves.

On the other hand, how much sterilization was really necessary? If the CNB did not defend the nominal exchange rate so fiercely, they would not have had to sterilize to the extent they did. The interest rate differential with Germany did not reflect a risk premium, but rather an opportunity for higher interest on Czech denominated assets. In the third quarter of 1995, the restriction on banks from accepting short-term foreign liabilities allowed larger banks to utilize cheaper, longer-term foreign loans. The policy lengthened the effective maturity of the inflows, better for banking system stability. But they helped institutionalize a two-tier banking sector, especially indicated in the return on contributed funds (see Table 7). It seems obvious that the lower lending profit margins contributed to the eight bank failures in 1996. These bank failures incurred costs of lost confidence, restricted competition, and lower future growth that are difficult to calculate but are likely significant. Worse yet, loans may not have been made available to firms which could have undergone restructuring. The painful loss may have been more easily endured during the period studied, a period of strong Czech growth, rather than in a later period, perhaps a first "normal" recession. 
Table 1

Lending by Banks: Different Break-downs

Table 1A. Large vs. Small Banks

\begin{tabular}{c|c|c|c|c|c|c|c|c|c}
\hline \hline \multirow{2}{*}{} & \multicolumn{4}{|c|}{1993} & \multicolumn{3}{c|}{1994} & \multicolumn{3}{c}{1995} \\
\cline { 2 - 11 } & Loans & L/TA & Mkt Sh & Loans & L/TA & Mkt Sh & Loans & L/TA & Mkt Sh \\
\hline Small & 94.9 & $55.2 \%$ & $17.0 \%$ & 129.1 & $56.8 \%$ & $19.7 \%$ & 108.3 & $46.1 \%$ & $16.1 \%$ \\
\hline Large & 462.0 & $54.3 \%$ & $83.0 \%$ & 527.9 & $53.1 \%$ & $80.3 \%$ & 566.0 & $48.2 \%$ & $83.9 \%$ \\
\hline \hline
\end{tabular}

Banks are classified as large if their assets are above 100 bn Kc

Table 1B. Banks with Low "Own Funds"

\begin{tabular}{c|c|c|c|c|c|c|c|c|c}
\hline \hline & \multicolumn{4}{|c|}{1993} & \multicolumn{3}{c|}{1994} & \multicolumn{3}{c}{1995} \\
\cline { 2 - 11 } & Loans & L/TA & Mkt Sh & Loans & L/TA & Mkt Sh & Loans & L/TA & Mkt Sh \\
\hline Low & 101.3 & $54 \%$ & $18 \%$ & 117.6 & $51 \%$ & $18 \%$ & 130.5 & $42 \%$ & $19 \%$ \\
\hline High & 147.6 & $66 \%$ & $27 \%$ & 195.1 & $65 \%$ & $30 \%$ & 178.4 & $55 \%$ & $27 \%$ \\
\hline C.S. & 112.0 & $35 \%$ & $20 \%$ & 119.1 & $33 \%$ & $18 \%$ & 119.8 & $33 \%$ & $18 \%$ \\
\hline K.B. & 196.1 & $67 \%$ & $35 \%$ & 225.1 & $68 \%$ & $34 \%$ & 245.6 & $60 \%$ & $36 \%$ \\
\hline \hline
\end{tabular}

Banks are classified as low if own funds vs. total assets are below 0.085 in 1994. "Own funds" are the owner's share of funds in the enterprise and thus include total capital plus reserves for bad loans. Those banks with low own funds per total assets in 1994 which remained in the data base in 1995 maintained their market share in the later year. Loans are in billions of Czech Koruny. C.S. is Cesky Sporitelna and K.B. is Komercni Banka.

Table 1C. Foreign vs. Domestic Banks

\begin{tabular}{c|c|c|c|c|c|c|c|c|c}
\hline \hline & \multicolumn{4}{|c|}{1993} & \multicolumn{3}{c|}{1994} & \multicolumn{3}{c}{1995} \\
\cline { 2 - 11 } & Loans & L/TA & Mkt Sh & Loans & L/TA & Mkt Sh & Loans & L/TA & Mkt Sh \\
\hline Foreign & 61.7 & $52.7 \%$ & $11.1 \%$ & 82.5 & $56.6 \%$ & $12.6 \%$ & 86.6 & $48.4 \%$ & $12.8 \%$ \\
\hline Domestic & 495.2 & $54.7 \%$ & $88.9 \%$ & 527.9 & $53.4 \%$ & $87.4 \%$ & 587.7 & $47.8 \%$ & $87.2 \%$ \\
\hline \hline
\end{tabular}


Table 2

\section{The Missing Banks}

CAspekt Bks

\begin{tabular}{lr|ll}
\hline Cash & 57.7 & 294.6 & IB Liab \\
IB As & 273.8 & 647.6 & Dep \\
Loans & 631.6 & 58.9 & Oth.Liab \\
Bills & 41.4 & 109.6 & Own K \\
Tot.Ast & 1125.7 & &
\end{tabular}

SAspekt Bks

\begin{tabular}{lr|ll}
\hline Cash & 58.0 & 297.7 & IB Liab \\
IB As & 279.9 & 768.8 & Dep \\
Loans & 733.3 & 87.0 & Oth.Liab \\
Bills & 63.2 & 168.2 & Own K \\
Tot.Ast & 1331.8 & &
\end{tabular}

CAspekt Bks

\begin{tabular}{lr|ll}
\hline Cash & 112.4 & 383.5 & IB Liab \\
IB As & 293.7 & 853.2 & Dep \\
Loans & 747.4 & 117.5 & Oth.Liab \\
Bills & 110.0 & 160.9 & Own K \\
Tot.Ast & 1532.1 & &
\end{tabular}

1993

\begin{tabular}{lr|ll}
\multicolumn{4}{c}{ Others } \\
\hline Cash & 22.9 & 21.3 & IB Liab \\
IB As & 3.7 & 51.6 & Dep \\
Loans & 38.0 & 8.3 & Oth.Lia \\
Bills & 12.8 & 38.2 & Own K \\
Tot.As & 122.0 & &
\end{tabular}

1994

Others

\begin{tabular}{lr|ll}
\hline Cash & 33.4 & 61.1 & IB Liab \\
IB As & 21.5 & 61.2 & Dep \\
Loans & 62.9 & 25.0 & Oth.Lia \\
Bills & 11.4 & 28.4 & Own K \\
Tot.As & 166.0 & &
\end{tabular}

1995

Others

\begin{tabular}{lr|ll}
\hline Cash & 78.1 & 81.2 & IB Liab \\
IB As & 23.3 & 98.9 & Dep \\
Loans & 128.0 & 141.0 & Oth.Lia \\
Bills & 45.9 & 49.3 & Own K \\
Tot.As & 353.0 & &
\end{tabular}

The missing bank balance sheets were obtained by subtracting the sum of the Aspekt data (the left column of balance sheets) from the totals given by the CNB in their publication Banking Supervision in the Czech Republic.

Approx. 4\% of the total assets in the Aspekt data set in 1995 were discarded due to unreliability.

Table 3

Behavior of M2 Multiplier

\begin{tabular}{c||c|c|c}
\hline \hline & 1993 & 1994 & 1995 \\
\hline \hline $\mathrm{c}$ & .10 & .12 & .12 \\
\hline $\mathrm{e}$ & .03 & .05 & $.13^{*}$ \\
\hline $\mathrm{t}$ & .50 & .53 & .59 \\
\hline $\mathrm{r}_{\mathrm{DD}}$ & .09 & .12 & .085 \\
\hline $\mathrm{r}_{\mathrm{TD}}$ & .03 & .03 & .085 \\
\hline$\mu$ & 5.58 & 4.46 & 3.33 \\
\hline
\end{tabular}

See equation $3 ; \mathrm{c}=$ currency $/(\mathrm{TD}+\mathrm{DD}), \mathrm{e}=$ excess reserves $/(\mathrm{TD}+\mathrm{DD}), \mathrm{t}=\mathrm{TD} /(\mathrm{TD}+\mathrm{DD}), \mathrm{f}=$ foreign exchange deposits /(TD $+\mathrm{DD}$ ), assumed 0 (in practice, f fluctuated little over time except for SPT deposit in $3^{\text {rd }}$ qtr, 1995) The multiplier was calculated using values of variables at the end of each year.

* For the first 3 qtrs of $1995, \mathrm{e}=.07$ for a multiplier $=4.1$. 
Table 4

Brief Balance of Payments (Kc bn)

\begin{tabular}{|c|c|c|c|c|c|c|c|c|c|c|c|c|}
\hline Year \& Qtr & $93 / 1$ & $93 / 2$ & $93 / 3$ & $93 / 4$ & $34 / 1$ & $94 / 2$ & $94 / 3$ & $94 / 4$ & $25 / 1$ & $95 / 2$ & $95 / 3$ & $95 / 4$ \\
\hline Curr & 12.4 & 10.5 & 4.0 & -14.3 & 10.2 & 7.4 & -2.8 & -6.5 & 4.0 & -3.5 & 1.2 & -18.4 \\
\hline on-res Capital & $\| 10.6$ & 27.1 & 8.3 & 30.9 & 14.4 & 10.0 & 15.0 & 30.9 & 36.9 & 24.7 & 71.2 & 62.5 \\
\hline Fgn. Dir. Inv. & 8.5 & 2.1 & 1.4 & 3.1 & 2.3 & 6.5 & 4.7 & 10.7 & 2.9 & 7.3 & 42.0 & 14.8 \\
\hline Portfolio & 4 & 10.9 & 9.8 & 10.2 & 6.0 & 9.8 & 6.1 & 1.8 & 2.3 & 14.6 & 8.2 & 17.8 \\
\hline Other Capital & 2.1 & 14.1 & -2.8 & 17.7 & 6.2 & -6.2 & 4.2 & 18.4 & 31. & 2.8 & 21.0 & 29.9 \\
\hline Errors \& Omis. & $\mid 10.8$ & -7.7 & 15.4 & 1.8 & 3.9 & .2 & -5.7 & -1.0 & $\$ 7$ & 5.4 & 1.1 & 14.0 \\
\hline X Reserves & 12.2 & -29.9 & -27.7 & -18.5 & 20.7 & -17.7 & -6.5 & -23.3 & 39.7 & -26.6 & -73.5 & -58.1 \\
\hline
\end{tabular}

*Source: Czech National Bank; Positive entries in capital accounts indicate capital inflows; Negative entries in FX Reserves indicate increase in Czech National Bank's foreign exchange reserves. Large FDI entries include large deals such as 37 bn Kc purchase of Czech Telecom in 1995

Table 5

CNB's Degree of Sterilization

\begin{tabular}{c|c|c|c}
\hline \hline & 1994 & 1995 & $1995(Q I-I I I)$ \\
\hline \hline$\Delta$ FX holdings, offset by: & 68.2 & 197.9 & 139.8 \\
\hline Increase in CNB bills & 20.4 & 74.9 & 11.6 \\
\hline Special accounts* & - & 42.3 & 42.3 \\
\hline \hline Reserve Requirements $* *$ & 4.9 & 16.8 & 11.9 \\
\hline \hline Share of FX sterilized & $37.1 \%$ & $67.7 \%$ & $47.1 \%$ \\
\hline$\Delta \mathrm{MB}$ & 38.6 & 123.2 & 50.0 \\
\hline$\Delta \mathrm{D}$ & 37.7 & 1.0 & -17.8 \\
\hline $\begin{array}{c}\Delta \mathrm{M} 1 \\
(\text { growth })\end{array}$ & $\begin{array}{c}61.9 \\
(17.2 \%)\end{array}$ & $\begin{array}{c}30.3 \\
(7.1 \%)\end{array}$ & -6.6 \\
\hline$\Delta \mathrm{T}$ & 84.7 & 110.3 & 69.9 \\
\hline $\begin{array}{c}\Delta \mathrm{M} 2 \\
(\text { growth })\end{array}$ & $\begin{array}{c}150.0 \\
(20.8 \%)\end{array}$ & $\begin{array}{c}139.6 \dagger \\
(16.0 \%)\end{array}$ & 62.4 \\
\hline
\end{tabular}

In billions of $\mathrm{Kc}$.

* The CNB transferred deposits from the National Privatization Fund and the SPT

Telecom away from the commercial banks. In the case of the SPT, a 27 bn Kc foreign exchange deposit was placed abroad yet also included in M2.

** Based on the idea that to sterilize an inflow into a bank deposit of $1 \mathrm{Kc}$, (1-rr) must be cut from the MB for the bank to have unchanged lending opportunities. I used shares of deposits as of the end of the year.

$\dagger$ Excludes the SPT's Kc 27 bn foreign exchange deposit held abroad 
Table 6

1 Kc Loan Cost using Different Funds Sources

\begin{tabular}{c|c|c|c|c}
\hline \hline & \multicolumn{2}{|c|}{1994} & \multicolumn{2}{c}{1995} \\
\hline \hline Quarter & I, II & III, IV & I, II & III, IV \\
\hline \hline Avg. Rate on New Credits & $12.9 \%$ & $13.1 \%$ & $13.3 \%$ & $13.3 \%$ \\
\hline DD & $12.7 \%$ & $16.6 \%$ & $16.4 \%$ & $12.1 \%$ \\
\hline TD & $14.3 \%$ & $13.8 \%$ & $13.7 \%$ & $20.4 \%$ \\
\hline Domestic Interbank & $8.4 \%$ & $9.9 \%$ & $10.6 \%$ & $11.2 \%$ \\
\hline Expected Depreciation* & $3.1 \%$ & $3.4 \%$ & $-0.4 \%$ & $-1.2 \%$ \\
\hline German Interbank (3 mo) & $6.0 \%$ & $5.0 \%$ & $4.8 \%$ & $4.3 \%$ \\
\hline DM deposit** & $4.1 \%$ & $4.1 \%$ & $4.1 \%$ & $4.1 \%$ \\
\hline
\end{tabular}

Entries reflect that to make a $1 \mathrm{Kc}$ loan, a bank must collect deposits of 1/(1-rr) to have sufficient funds remaining in order to satisfy the reserve requirement.

* based on perfect foresight 6 mo. avg.. DM exchange rate in future. Add this row to foreign rates for cost of using German deposits since a Czech bank borrowing at the German interbank rate must repay a foreign deposit in more expensive DM.

** based on the Bundesbank reserve requirement of $2 \%$ on time deposits and a $2 \%$ time deposit rate.

Table 7

\section{Lending by Bank Ownership and Access to Foreign Funds}

\begin{tabular}{c||c|c|c|c||c|c|c|c||c|c|c|c}
\hline \multicolumn{1}{l|}{} & \multicolumn{5}{c|}{1993} & \multicolumn{4}{|c|}{1994} & \multicolumn{4}{c}{1995} \\
\hline \hline Local & ER/TA & Loans & L/Mkt & R/OF & ER/TA & Loans & L/Mkt & R/OF & ER/TA & Loans & L/Mkt & R/OF \\
\hline \hline F-owne & $0.5 \%$ & 115 & $21 \%$ & $4.6 \%$ & $0.1 \%$ & 150.2 & $22 \%$ & $1.0 \%$ & $2.8 \%$ & 141.4 & $21 \%$ & $0.1 \%$ \\
\hline F-acces & $0.4 \%$ & 37.4 & $10 \%$ & $-21.3 \%$ & $0.4 \%$ & 69 & $11 \%$ & $1.2 \%$ & $2.2 \%$ & 68.5 & $10 \%$ & $1.4 \%$ \\
\hline
\end{tabular}

Loans are in Kc billions. The market share columns represent only those banks in the data set. Banks were determined to have access to foreign funds in 1995 if their interbank deposits increased more than 10 bn Kc over their interbank assets between the years 1994 and 1995. Banks in this group include Komercni Banka, Cesky Sporitelna, Ceskoslovenska Obchodni, Citibank, and Creditanstalt. 


\section{References}

Anderson, Ronald and Eric Berglof (1996) "Organization of Banks in the CEE Economies" in Anderson, Berglof, and Mizei eds. Banking Sector Development in Central and Eastern Europe

Anderson, Ronald and Chantal Kegels (1997) "Finance and Investment in Transition: Czech Enterprises, 1993-1994" mimeo

Bank for International Settlements (various years) The Maturity and Sectoral Distribution of International Bank Lending

Bernanke, Ben and Alan Blinder (1992) "The Federal Funds Rate and the Channels of Monetary Transmission” American Economic Review

Bernanke, Ben and Cara Lown (1991) "The Credit Crunch" Brookings Papers on Economic Activity

Blomgren-Hansen, Niels (1984) Danske Pengepolitik - Teori og Erfaringer

Boyd, John and Mark Gertler (1993) "U.S. Commercial Banking: Trends, Cycles, and Policy" NBER Working Paper 4404

Calvo, Guillermo and Fabrizio Coricelli (1993) "Output Collapse in Eastern Europe: the Role of Credit" in Blejer, Calvo, Coricelli, Gelb, eds. Eastern Europe in Transition: From Recession to Growth? World Bank Discussion Paper 196

Calvo, Guillermo, Leonardo Leiderman, and Carmen Reinhardt (1996) Inflows of Capital in Developing Countries in the 1990's" Journal of Economic Perspectives

Camdessus, Michel (1994) "Supporting Transition in Central and Eastern Europe: An Assessment and Lessons from the IMF's Five Years' Experience” 2nd Fransisco Ordonez Address

Caprio, Gerard (1995) "The Role of Financial Intermediaries in Transitional Economies" CarnegieRochester Conference Series on Public Policy 42, 257-302

Czech National Bank Annual Report, 1993-1996

Czech National Bank (1995) Banking Supervision in the Czech Republic

De Grauwe, Paul (1994) The Economics of Monetary Integration, 2nd ed.

Deutsche Bundesbank (1995) Die Geldpolitik der Bundesbank

Economist (April 12, 1997) "Banking in Emerging Markets"

Friedman, Milton and Anna Schwarz (1963) A Monetary History of the United States

Hanousek, Jan and Josef Kotrba "Czech Banking in Transition, 1990-1996" mimeo

Kashyap, Anil and Jeremy Stein (1995) "The Impact of Monetary Policy on Bank Balance Sheets" Carnegie-Rochester Conference Series on Public Policy 42 
Krugman, Paul and Maurice Obstfeld (1997) International Economics - Theory and Policy, 4th ed.

Lewis, Karen K. (1995) "Puzzles in International Financial Markets" in Handbook of International Economics, Volume III

Mishkin, Frederic (1992) The Economics of Money, Banking and Financial Markets

Mussa, Michael (1979) "Empirical Regularities in the Behavior of Exchange Rates and Theories of the Foreign Exchange Market" in Brunner and Meltzer, eds. Policies for Employment, Prices, and Exchange Rates

Sharpe, Steven (1995) "Bank Capitalization, Regulation, and the Credit Crunch: A Critical Review of the Research Findings” Board of Governors FEDS Working Paper

Vojtisek, Petr (1993) "Restructuring of the Banks in the Former Czech and Slovak Federal Republic" in OECD Transformation of the Banking System 

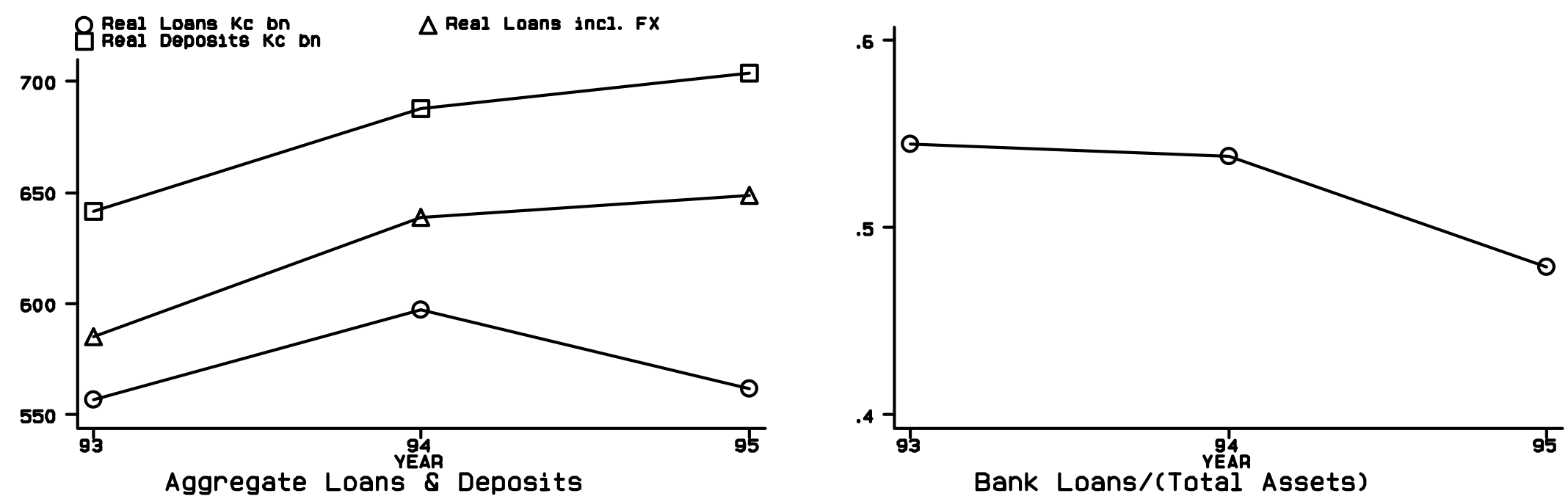

Figure 1 

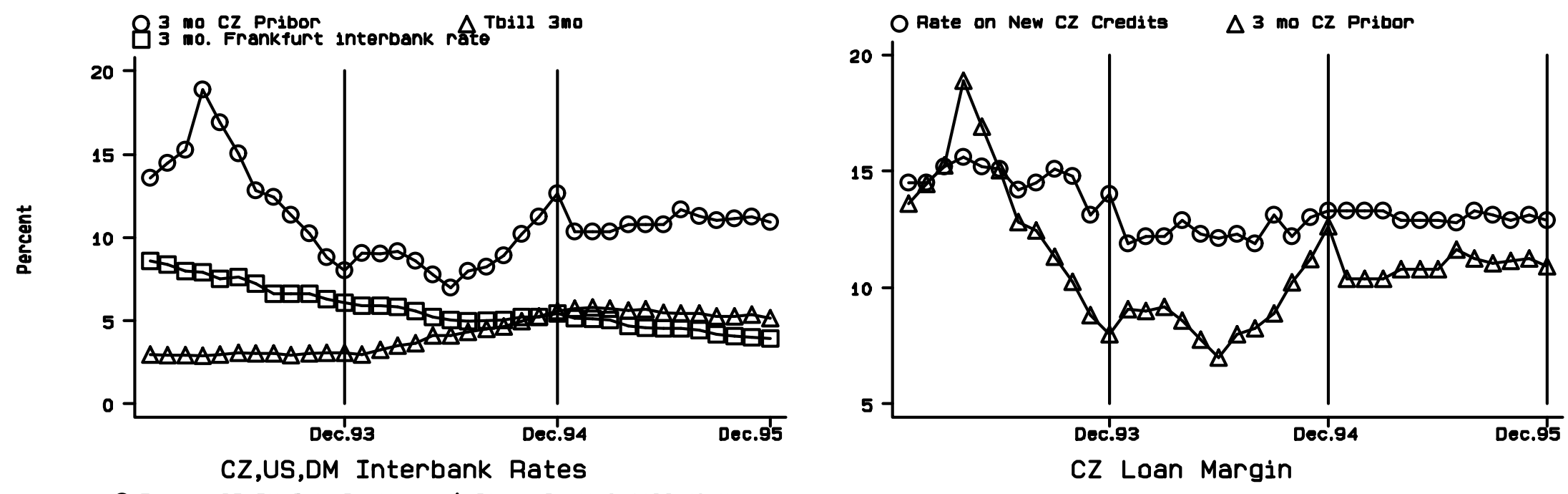

O Excess CZ-DM Int. Parity $\Delta$ Other Capital (100mil KC)

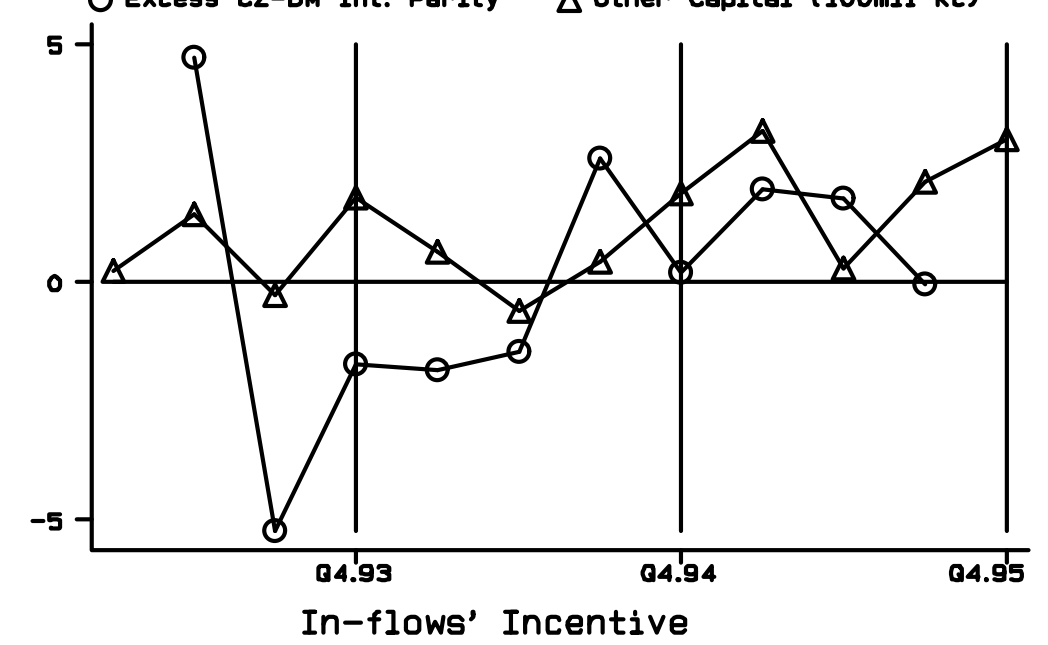

Figure 2 